\title{
INTERNALIZATION OF ULUL ALBAB VALUE (A STUDY OF LIVING QUR'AN AMONG THE STUDENTS OF UIN MALANG)
}

\author{
Izzah Faizah Siti Rusydati Khaerani \\ Sunan Gunung Djati State Islamic University (UIN) Bandung \\ izzahfaizahsiti@uinsgd.ac.id \\ Afif Muhammad \\ Sunan Gunung Djati State Islamic University (UIN) Bandung \\ Syihabuddin \\ Indonesian University of Education Bandung
}

\begin{abstract}
The process of applying the Qur'anic messages becomes very important to be studied by every Muslim. Ulul Albab is part of Al-Qur'an concept which has long been applied and customized by the students in Maulana Malik Ibrahim State Islamic University, Malang. This application process is important to know that the design can be adopted by the public at broad range. The purpose of this study is to know (1) the ulul Albab values that are understood by the students, (2) mechanism of internalization process of ulul albab values on students. The method used is a case study to illustrate how the values of ulul albab are internalized in everyday life.
\end{abstract}

Keywords: Education, Internalization, Living Qur'an, Ulul Albab, Value.

\section{Introduction}

Religious values should be used as a reference for the development of the institutions. They have been implemented in education and business.. Several countries like Bangladesh, Indonesia and Morocco's implemented Islamic values in educational and industry policies (Amaliah, Aspiranti, \& violet Gibbs, 2015; Asadullah \& Chaudhury, 2010; Forster \& Fenwick, 2015). Values will be effective when tansferred through creative and systematic methods, ranging from discussions of moral, an environment's dilemma to development professional (Berkowitz, 2011).

This research attempts to examined the implementation of Ulul Albab values- the term derived from the Qur'an - as a prototype profiles for graduates at the UIN Malang. There are several research have been done on Ulul Albab,. Among others was conducted by Al-Walid who studied the educational model of Ulul Albab character in Maulana Malik Ibrahim State University, Malang. He explains that ulul albab character aims to foster a Muslim who has ulul albab values. Ulul albab values cover religious values, patient, sincere, tawakkal, tawadlu ', istiqamah, submissive, fair, honest, gentle, passionate/high spirited, critical, knowledgeable, intelligent, caring, empathy, tolerance, cooperation, professional (Walid, 2011: 152-153). Abdul Basid found that ulul albab personality visualize in scientists figure (Basid, 2012: 1). Other research by Sri Aliyah examines the characteristics of ulul albab in Tafsîr Fî̀ dzilal Al-Qur'ân. She stated that ulul albab is the person who combines dzikr and thought (Aliyah, 2016: 115-150).

From the above mentioned researches stated above, there are apparently no research specifically examines the process of internatisation of ulul Albab values. The process of internalization is indeed part of a study that examines the living Qur'an derived from various understanding and interpretation of the Qur'an. Ulul albab 
is a concept that includes internalized to the students. The concept of the Qur'an that are prepared to be adapted in a practical level. In this case I refer to as applied interpretation: any understanding sistematically implemented by person or agency with the goal to keep the messages of the Qur'an. These implementation can be turned to the pattern of life and customs of the community or certain groups.

\section{Method}

This research employs qualitative method to understand social life of the research proses. Data gathered by interviewing the participants to find out their opinions, thoughts and perceptions. Observation also used to analyze the patterns. This is a case study research for analysing a particular case of its problems, difficulties, obstacles and/or deviations (Sukmadinata, 2007:77). In case studyalsonecessary to perform an activity or process and the data concentrated on one phenomenon to be understandtood in depth (McMillan and Schumacher, 2001: 398). Case study is an approach to study, explain, or interpret a case in context naturally without the intervention of outside parties (Schramm in Salim, 2001:93).

The data obtained from the subjects of this research consist of the maindata in the form of words and actions (primary). This case study was conducted in UIN Maliki Malang. Participants of this research include the leaders, lecturers, employees of UIN Maliki Malang, as well as the students. Additional data are also analized in the form of documents (secondary). So some data sources are utilized in this research include primary data andsecondary data. Primary data is data obtained through interviews and observation, while secondary data taken from written document (Arikunto, 2006: 115).

\section{Discussion}

1. Values Internalization

Internalization is the pattern of a deepening of the teachings, doctrines, or values so that it is a belief and awareness of the truth of a doctrine or values that are embodied in the attitude and behaviour. Ryan (1983:23) explains that internalization is: "The term internalization refers to the process by which an individual acquired an attitude, belief, or behavioral regulation from external sourcess and progressively transforms it into a personal value, goal, or organization." (the term internalization refers to the process by which a person obtains an attitude, belief, or regulation over the behavior of the external sources that progressively change their personal values and the achievement of its purpose or organization). Thus, internalization in this article is an attempt to internalize by unifying external values and norms within a person's mind and then become inherent in the behaviour and life. Basically, internalization also place particular value on individuals through specific strategies and methods. In practice, the orientation of values, culture and learning influenced the process of internalization. Value orientation affect the commitment of the organizations that in turn will determine the learning process. A study related to the orientation of value in the workplace and organizational commitment to primary school teachers and secondary schools showed that there is a relationship between value orientation and the commitment of the organization. (Shaw, 1992: 295-302) 

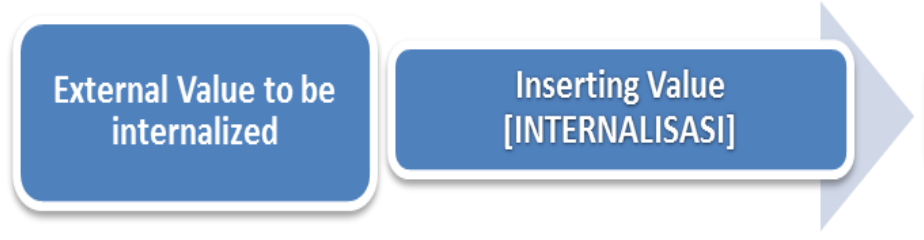

Figure 1

\section{Individual}

Fundamental of Internalisation

The process of internalization can be done through socialization: Socialization is the total process in which individual develops a human personalityand learn to be a social actor. (Syamsul Arifin, 2011:38 or may be internalized through techniques of clarification. (Lisievici \& Andronie, 2016)

Fraenkel (1977: 6) stated that a value is an idea-a concept-about what someone thinks is importent in life Therefore the value is generated by the experience of culture, society and personal and inherently internalized in individual psychological structure and become durable and stable. Thus the values have both tendencies to settle and to change by many factors. These values not only talk about things that already exist in the community, but also demandthings that should exist in the community. (Türkkahraman, 2014) Family and Social environment and even educational institutions affect the values espoused. (Shobha \& Kala, 2015)

Thomas Lickona (2012:62) divides the value into two kinds, namely moral and nonmoral values. Moral values are values that demands to be implemented like honesty, responsibility and justice are values required to be done. Although it is not to be easy to do. Differ from that of moral, non-moral does not demand to be implemented to oneself and $t$ other. The example of non-moral values is enjoying the beautiful scenery. This value contain goodness and calmness. However, this value is not required to be acquired.

In addition, moral values are divided into two categories, namely universal moral values and non universal moral values. Universal moral values are values that demanded by everyone to gain and to be acquired. On the contrary, non universal vaues are the value that not every people need to acquired. For example the practice of fasting for Muslim gain reward of kindness, while for non-Muslim does not give any good value on it. However, morality and religion have a strong attachment in assessing person's behavior in both affirming and strengthening mutual universal values. Thomas Lickona mentions that respect and responsibility as the primary moral values. The value referred to by humans who have different sources. Kosasih Djahiri (1996: 23) and Asyafah (2009:173) mentions that it's value comes from four sources, i.e: religion, philosophy, law and culture. The value of the source makes reference to judge between good to bad, right to wrong, improper to inappropriate. Religion in general also discuss about the value and served as a source value. Reasonable thoughts become instruments to understand and clarify the value of the source. In the view of Ahmad Sanusi (Asyafah, 2009: 174) religious values are more easily to be accepted since they contain dogmatic belief by it adherents.

2. Values of Ulul Albab at UIN Malang and Internalisation Proces

a. Values of Ulul Albab

The term ulul albâb found in 16 verses in the Qur'an. These verses discuss about personal characteristics of ulul albâb which include the quality of Dhikr, fikr ' and good deed(amal saleh). These values can be seen in daily life such as: (1) 
Possess the sharpness of analysis; (2) possess the sensitivity of spiritual exercises (4) possess the optimism in life; (5) contain a balance between physical- spiritually; social and individual-the balance of the world and the hereafter. (5) have the benefit to humanity; (6) Become pioneer in social transformation; (7) has the independence and responsibility; (8) and possess the sturdy personality ( Center for the study of Ulul ' Albâb, 2010: 45).

In practice, Personality of ulul albâb means producing scientists who are able to explai $n$ the verses of Allah SWT to the community. Therefore scientists must build albâb be ulul fo stering the younger generation in order to (1) have a broad knowledge of science; (2) the shar p vision; (3) an intelligent Brain. (4) a soft heart, (5) high spirit because God Almighty (Basri, ed. 2010, p. 46). In order to obtain a broad knowledge, keen eyesight, a smart brain, then needed a soft heart that is a heart that is willing to accept the truth of God Almighty. (Basri, ed. 2010: 45-76).

Ulul albâb values can also be elaborated into a structure, i.e. the concept of spiritual depth, Majesty of morals, vastness of the science and professional maturity. These values will build spiritual strength and moral simultaneously so that later formed into a powerful personal and tough. (Shobha \& Kala, 2015)This variable has the basic competences outlined in the table below.

Table 1

Competence Grid Tarbiyah Ulul albâb

\begin{tabular}{|c|c|c|}
\hline NO & VARIABLE & BASIC COMPETENCE \\
\hline \multirow{3}{*}{1} & \multirow{3}{*}{$\begin{array}{l}\text { Spiritual depth } \\
\text { (1) }\end{array}$} & 1. Awareness of Allah's presence \\
\hline & & 2.Ability to admire Allah's creation \\
\hline & & 3. fear nothing but Allah \\
\hline \multirow{3}{*}{2} & \multirow{3}{*}{$\begin{array}{c}\text { Majesty of morals } \\
\text { (2) }\end{array}$} & 1. improving his quality of life \\
\hline & & 2. patients/Shabr upon trial \\
\hline & & 3. ability to distingushed good and bad \\
\hline \multirow{3}{*}{3} & \multirow{3}{*}{$\begin{array}{l}\text { vastness of the science } \\
\text { (3) }\end{array}$} & 1.seeking knowledge seriously \\
\hline & & 2. optimizing his brain/,,aql \\
\hline & & 3. ability to use his qalbu (heart) \\
\hline \multirow{3}{*}{4} & \multirow{3}{*}{$\begin{array}{c}\text { professional maturity } \\
\text { (4) }\end{array}$} & 1. act based on knowledge \\
\hline & & 2. ready to serve the ,ilmu knowledge \\
\hline & & 3. play role as a problem solver \\
\hline
\end{tabular}

Table 1 resources from Tarbiyah Ulul Albâb and research documentation of Ulul Albab Values internalization of UIN Malang

Table 2

Meaning of Ulul albâb according the Mufasser

\begin{tabular}{|l|l|l|}
\hline No & Name of Mufasir & \multicolumn{1}{c|}{ Meaning of ulul Albab } \\
\hline 1. & $\begin{array}{l}\text { Jalaluddin } \\
\text { As- Suyuthi } \\
\text { \& Al- }\end{array}$ & The one's who owns 'aql (ashâbu al 'uqûl) \\
\hline 2. & Ibnu Abbas & Owner of the 'aql "dzi al 'uqul min al-nas" \\
\hline
\end{tabular}


Table 2, Cont.

\begin{tabular}{|c|c|c|}
\hline $\mathrm{No}$ & Name of Mufasir & Meaning of ulul Albab \\
\hline 3. & Al-Khazin & $\begin{array}{l}\text { Owner of the 'aql and visioner (dzi al-'uqûl } \\
\text { wa al-bashâir) }\end{array}$ \\
\hline 4. & At-Tahabari & $\begin{array}{l}\text { One's who did deep research by his 'aql about } \\
\text { ayat- ayat (signs) of Allah. }\end{array}$ \\
\hline 5. & Al-Alusi. & $\begin{array}{l}\text { a. Person who take lesson and advice from ayahs } \\
\text { of Allah. } \\
\text { b. very Sincerely, God- } \\
\text { consciousness and knowledgeable } \\
\text { c. Possesing right ,aql from all types of dirty mind } \\
\text { and imagination } \\
\text { d. A wise person }\end{array}$ \\
\hline 6. & Ibn Hayyan & $\begin{array}{l}\text { a. Owner of 'aql } \\
\text { b. Succesful person } \\
\text { c. Alwas do ,amal as a form of pious } \\
\text { d. Do all Allah's command } \\
\text { e. Avoid Allah'sprohibition } \\
\text { f. Keep his promises } \\
\text { g. Avoiding satan's deed } \\
\text { h. Believe in Allah's promises } \\
\text { i. Preserving aql funnction as--furqan- } \\
\text { distinguish good and bad. } \\
\text { j. Not negligent in utilizing common sense in life } \\
\text { k. bearing in mind and choosingthe Affairs to religion and } \\
\text { the worldly live }\end{array}$ \\
\hline 7. & Fakhru ar-Razi & $\begin{array}{l}\text { a. being able to perceive the virtue and knowledge } \\
b \text {. remember and take a lesson } \\
\text { c.aware of the policy and } \\
\text { knowledge comes solely from God }\end{array}$ \\
\hline 8 & Baidhawi & $\begin{array}{l}\text { Degree for people already deep } \\
\text { in knowledge include: } \\
\text { - the ability of the review (yatadabbarun) } \\
\text { - the ability of the menalar (ta'qilun) } \\
\text { - ability to observe (tabshirun) } \\
\text { - ability to understand (tafaqqahun/tafqahun) } \\
\text { - ability to think (tafakkarun) deterrent (ulî } \\
\text { - the ability of the contemplate (tadzkirun) } \\
\text { - ability to use reasonable an-nuha) }\end{array}$ \\
\hline 9 & Ibnu Abas & Knowledgeable, insightful \\
\hline 10 & Al-Baghawi & Knowledgeable, insightful \\
\hline
\end{tabular}

From some of the above interpretation, keyword ulul albab is personal, which enable the mind and heart to the maximum, he is knowledgeable and able to judge the good bad, capable of acting as a professional personal that is reflected by its ability avoid behavior that is futile. This personal is able to visualize into the spiritual, moral 
grandeur, breadth of knowledge and professional maturity as internalized by the student to the University of UIN Malang. Through a series of activities of analysis and discussion, then the values are visualized albâb ulul students called factual value. The values found include; 1) honestly; 2) discipline; 3) cooperation; 4) hardwork; 5) selfconfidence; 6) responsibilities;7) tolerance; 8) curiosity; self-catering and 9) tough (11) Benefactor those are factual values.

b. Internalization process of Ulul Albab values

While in General, the mechanism of internalization of the values of ulul albâb at UIN Malang also involves three important phases i.e. knowing moral, moral feeling and moral behavior. These three stages each have different competence where a moral knowing has the competence of knowing the good, moral feeling has competence, desire the good and moral behavior has the competence of doing the good. While these three indicators we can see on the habit of mind, a habit of heart and habit of action.

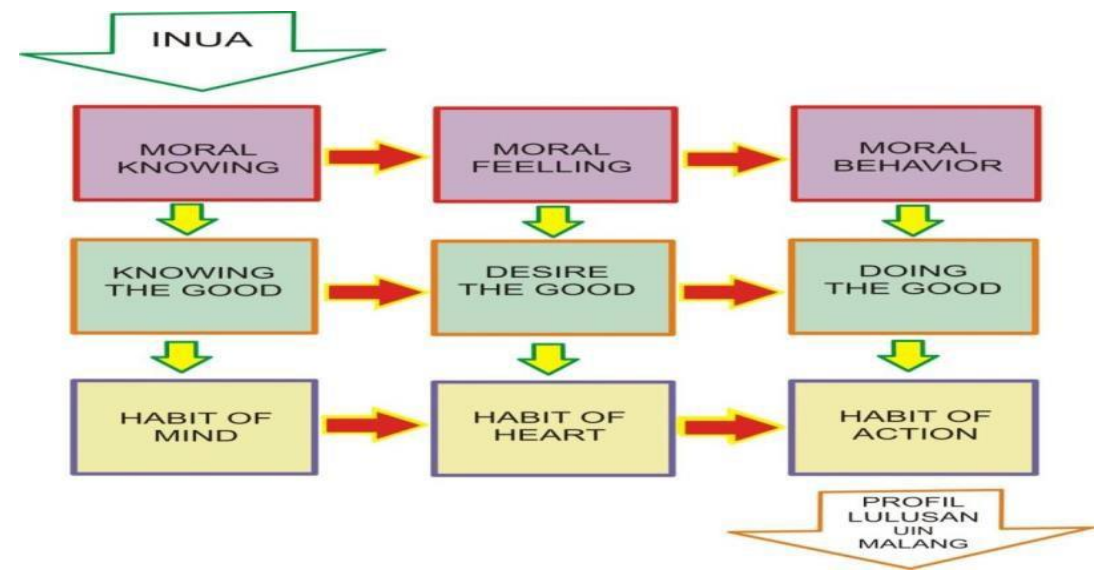

Figure 2

Mechanism of internalization of values Education about Theory albâb ulul referred to the character Thomas Lickona

In simple terms we take for example the above mechanism based on the author'sfindings in the field. View log book observations on the activity of the khatmil of the Qur'an the activist nature lover will do mountaineering (HO. 4.3) as well as the results of the author's interviews with activists of the lover of nature (M3. b). at an early stage, the students know the true about the duty of reading the Qur'an as a muslim and it is a command from God as a guide for mankind (a moral knowing), further knowledge of the Qur'an reading is believed to as one form of servitude on the Almighty (knowing the good), so the conviction becomes an instrument fordividing things that good religion or bad thing according to religion is hardwiredor already an arrangement the value in itself (habit of mind). This knowledge preceded through discussion and dialogue as part of the process of internalization. This dialogue is viewed will be able to strengthen the process of understanding the values that are being internalized.(Álvarez, 2014)

The next stage is the strengthening of the habit of mind, values that were formedbecame the corner stone in determining viewpoints towards the activity of the khatmil of the Qur'an as a good and rewarding activities for him (moral feeling) this stage of childbirth the competence of the students to have a desire to do so in his life (desire of good) hitting from the heart continuously as well as establish conditioning (habit of 
heart).

The final stage, the behavior already dignity are inseparable in life (moral behavior) makes her feel "lost" or something less when not doing what became a ritual that's been membiasa for him (doing the good). In the end khatmil the behavior of the Koran being internalized in personality of the student (habit of action).

Lickona (1992:126) which looked at the value of personalization is divided into three interrelated fields i.e. knowing moral, moral feeling and moral behavior. Therefore, the good personality contains three competencies, i.e. knowing good things (knowing the good), there is a desire of the good (desiring the good), and doing good things (doing the good) so that he in turn will become the habit of thinking (habits of mind), habits of the heart (habits of heart) and 'custom action'(habits of action).

\section{Conclusion}

Ulul albab have personal values of (1) honesty; discipline; cooperation; hard work; confident; responsibility; tolerant; has the curiosity of a high (critical); independent, tough, generous. The values of the visualization of spiritual depth, Majesty of morals, the breadth of knowledge and maturity of the profesioanal reflected in Dhikr,charitable and pious thought. (2) the process of internalization is carried out through three phases namely knowing moral, moral feeling and moral behavior.

In general, both internalization mechanism of ulul albab values were directing at the some point to produce graduate of UIN Maliki Malang as revealed in Intisitute Vision and Mission with the character of Dzikr, Fikr and 'Amal shaleh.

\section{References}

Aliyah, S. 2016. Ulul Albab Dalam Tafsir Fi Zhilali Al-Quran. Jurnal Ilmu Agama, 14(1), 115- 150.

Álvarez, C. Á. (2014). Dialogue in the Classroom: The Ideal Method for Values Education in Multicultural Contexts. Procedia - Social and Behavioral Sciences, 132, 336-342. https://doi.org/10.1016/j.sbspro.2014.04.319

Amaliah, I., Aspiranti, T., \& Purnamasari, P. (2015). The Impact of the Values of Islamic Religiosity to Islamic Job Satisfaction in Tasikmalaya West Java, Indonesia, Industrial Centre. Procedia - Social and Behavioral Sciences, 211(September), 984991. https://doi.org/10.1016/j.sbspro.2015.11.131

Asadullah, M. N., \& Chaudhury, N. (2010). Religious Schools, Social Values, and Economic Attitudes: Evidence from Bangladesh. World Development, 38(2), 205217. https://doi.org/10.1016/j.worlddev.2009.10.014

Al Alusy, Syihabudin mahmud, (n.y) ruh al-ma'any fi al-tafsir al-Qur'-nashir al-Din Abu al- baidhawi, an al Adzim wa sab'il matsani, Bairut; Dar al-Fikr

Arifin, Syamsul, 2011. Pengembangan Model Internalisasi Nilai Toleransi Dalam Kehidupan Multikultural Melalui Pendidikan Agama Islam di Sekolah, Desertasi. UPI, Bansung

Al- Baidhawi, Nashir al-Din Abu al-Khair Abdullah Ibnu Umar, (n.y), Anwar -Tanzil wa Asrar al-Ta'wil. Bairut: Dar al-Fikr

Arikunto, S. 2006. Manajemen Penelitian. Jakarta: Rineka Cipta.

Asyafah, Abas 2009. Proses Kehidupan Manusia dan Nilai Eksistensialnya, Bandung: CV. Alfabeta.

Al Baidhawi, Nashir al-Din Abu al-Khair Abdullah Ibnu Umar, (n.y), Anwar -Tanzil wa Asrar al-Ta'wil. Bairut: Dar al-Fikr

Al-Baqi, Muhammad Fuad abd' 1981. Al-Mu'jam al-Mufahrash Li Alfadz Al-Qur'an al-karim, Bairut: Dar al-Fikr 
Al-Baghawi, (1993) Ali Muhammad Husain bin Mas'ud Al-Farra al-Syafi'i, Ma'alim al-Tanzil, Bairut: Dar al-Kutub al-Ilmiah

Basid, A. 2012. Ulul albab sebagai sosok dan karakter saintis yang paripurna. In PROSIDING: Seminar Nasional Fisika dan Pendidikan Fisika (Vol. Vol 1, No, pp. 281-291).

Berkowitz, M. W. (2011). What works in values education. International Journal of Educational Research, 50(3), 153-158. https://doi.org/10.1016/j.ijer.2011.07.003

Basri, ed. 2010. Bahan Ajar Tarbiyah Ulul Albab; Kepribadian dan Tanggug Jawab Ulul Albab, Pusat Studi Tarbiyah Ulul Albab UIN Malang. UIN Malang Press

Djahiri, Kosasih. 1996. Menelusuri Dunia Afektif Pendidikan Nilai dan Moral. Bandung: LPPMP-IKIP

Fraenkel, J.R. 1980. Helping Students Think and Value: Strategies for Teaching the Social Studies.Second Edition. New Jersey: Prentice-Hall, Inc.

Forster, G., \& Fenwick, J. (2015). The influence of Islamic values on management practice in Morocco. European Management Journal, 33(2), 143-156. https://doi.org/10.1016/j.emj.2014.04.002

Ibn Abbas, t.th tanwir al-miqbas,Bairut; dar al-fikr

Al-Khazin, Abu Al-Hasan „Ali, (n.y) Lubab al-ta'wilfi maani al-Tanzil, Kairo, Mu'assasah Ibn Hayyan, (n.y) Abu Al-Hayyan Muhammad Ibn Yususf Ibn Ali ibn yusuf, tafsir bahr al- muhith, Bairut, al-maktabh al-Syarqiyyah

Lickona, T. 2012. Educating for Character: How Our Schools CanTeach Respect and Responsibility. New York: A Bantam Book Publishing History.

Lisievici, P., \& Andronie, M. (2016). Teachers Assessing the Effectiveness of Values Clarification Techniques in Moral Education. Procedia - Social and Behavioral Sciences, 217, 400-406. https://doi.org/10.1016/j.sbspro.2016.02.111

Al-Razi, Abu Abdullah Muhammad ibn Umar ibn hasan Facr al-Din, (n.y) Mafatih alGhaib, Kairo; Dar al-Fikr

Ryan, R. M. et. al., Internalization and Motivation some Preliminary Research \& Theoritical Speculation", Paper presented at the Beinnial Meeting of the society the Research in Child Development $50^{\text {th }}$, Detroid, MI, April 21-24, 1983

Walid, M. 2011. Model pendidikan karakter di perguruan tinggi agama Islam (Studi tentang pendidikan karakter berbasis Ulul albab di Universitas Islam Negeri Maulana Malik Ibrahim Malang ), Jurnal Al-Qudwah, (April), 115-156.

Shaw, et.al. 1992. School Culture: Organization Value Orientation and Commitment. Jurnal of Education \& Research 85 n5 May-Jun

Shobha, S., \& Kala, N. (2015). Value Education towards Empowerment of Youth-A Holistic Approach. Procedia - Social and Behavioral Sciences, 172, 192-199. https://doi.org/10.1016/j.sbspro.2015.01.354

Sukmadinata, N.S. 2008. Metode Penelitian Pendidikan. Bandung: UPI-Rosda Karya.

Al-Suyuthi, Jalaluddin dan Jalaluddin al-mahalli, (n.y) Tafsir Jalalain, Bairut: Dar al-fikr

Al-Thabary, Muhammad Ibn Jarir, (t. Th) Jami al-Bayn fi Ta'wil al-Qur'an, Kairo: Muassasah al-Risalah

Türkkahraman, M. (2014). Social Values and Value Education. Procedia - Social and Behavioral Sciences, 116, 633-638. https://doi.org/10.1016/j.sbspro.2014.01.270 